\section{$B J N$ 'Citation Classic'}

We are pleased to reproduce on the following pages, in our occasional series of 'Citation Classics', the article by Simons et al. entitled "Improvement of phosphorous availability by microbial phytase in broilers and pigs", which appeared in the British Journal of Nutrition in September 1990. Interrogation of the Science Citation Index indicates that this is the most highly cited article published by the BJN during the 1990's; by September 2004 it had received a total of 300 citations. This figure is, of course, based only on those journals that are included in the Science Citation Index database and excludes citations in books and monographs, the true extent to which it has been cited is therefore even greater than the 300 citations recorded.
Paul Trayhurn

Editor-in-Chief

\section{Reference}

Simons PC, Versteegh HA, Jongbloed AW, Kemme PA, Slump P, Bos KD, Wolters MG, Beudeker RF \& Verschoor GJ (1990) Improvement of phosphorus availability by microbial phytase in broilers and pigs. $\mathrm{Br}$ J Nutr 64, 525-540. 


\title{
Improvement of phosphorus availability by microbial phytase in broilers and pigs
}

BY P. C. M. SIMONS AND H. A. J. VERSTEEGH

Spelderholt Centre for Poultry Research and Information Services, Spelderholt 9, 7361 DA

Beekbergen, The Netherlands

AND A. W. JONGBLOED AND P. A. KEMME

Research Institute for Livestock Feeding and Nutrition, PO Box 160, 8200 AD Lelystad,

The Netherlands

AND P. SLUMP, K. D. BOS AND M. G. E. WOLTERS

TNO CIVO-Institutes, PO Box 360, 3700 AJ Zeist, The Netherlands

AND R. F. BEUDEKER AND G. J. VERSCHOOR

Gist-brocades, PO Box 1, 2600 MA Delft, The Netherlands

(Received 10 October 1989 - Accepted 30 March 1990)

\begin{abstract}
Techniques have been developed to produce microbial phytase for addition to diets for simple-stomached animals, with the aim to improve phosphorus availability from phytate-P in plant sources. The activity of the crude microbial phytase showed $\mathrm{pH}$ optima at $\mathrm{pH}$ 5-5 and 25. The enzyme was able to degrade phytate in vitro in soya-bean meal, maize and a liquid compound feed for pigs. When microbial phytase was added to low-P diets for broilers the availability of $P$ increased to over $60 \%$ and the amount of $P$ in the droppings decreased by $50 \%$. The growth rate and feed conversion ratio on the low-P diets containing microbial phytase were comparable to or even better than those obtained on control diets. Addition of microbial phytase to diets for growing pigs increased the apparent absorbability of $P$ by $24 \%$. The amount of $P$ in the faeces was $35 \%$ lower.
\end{abstract}

Phosphorus availability: Microbial phytase: Broilers: Pigs

Feeds for poultry and pigs mainly contain ingredients of plant origin. About two-thirds of the phosphorus in these products is present as phytate-P which has a low availability in simple-stomached animals. It therefore contributes to the $\mathrm{P}$ pollution problems in areas having an intensive livestock production such as The Netherlands.

Many fungi, bacteria and yeasts produce the enzyme phytase which is needed for the hydrolysis of phytate to inositol and inorganic phosphate. Nelson etal. (1968) were the first to add phytase, produced by a culture of Aspergillus ficuum, to liquid soya-bean meal. The feed was incubated for $2-24 \mathrm{~h}$ at $50^{\circ}$. After drying, it was fed to 1-d-old chicks. The birds showed a considerable increase in bone ash percentage over controls receiving no inorganic phosphate. In a second experiment (Nelson et al. 1971), a preparation of phytase produced by Aspergillus ficuum was added to a complete diet for chickens. In this case the enzyme was shown to be active in the gastrointestinal tract. The supplemented diet containing 3-0 $\mathrm{g}$ total $\mathrm{P} / \mathrm{kg}$ and $1-8 \mathrm{~g} / \mathrm{kg}$ phytate- $\mathrm{P}$, gave similar tibia ash percentages as a control diet containing $1-6 \mathrm{~g} \mathrm{P} / \mathrm{kg}$ from disodium phosphate. They concluded that chicks utilized phytate-P as well as supplemental inorganic P.

To our knowledge comparable results with diets for pigs containing added microbial phytase have not been reported. Cromwell \& Stahly (1978) performed an experiment in 
which a dried live yeast culture of Saccharomyces cerevisiae was added to a maize-soyabean-meal diet for pigs $(15 \mathrm{~g} / \mathrm{kg})$. They concluded that the yeast culture probably did not improve the availability of phytate-P because growth rate, feed conversion ratio (intake $₹$ gain) and bone strength were not influenced. Similar conclusions were presented by Chappie et al. (1979) from an experiment in which $20 \mathrm{~g}$ live yeast culture/kg feed were substituted for maize in a diet for growing pigs. Growth rate, feed intake and feed conversion ratio were measured. However, an improvement in growth rate was observed in another experiment with pigs from 65 to $100 \mathrm{~kg}$ live weight on diets with $35 \mathrm{~g}$ total $\mathrm{P} / \mathrm{kg}$ (Shurson et al. 1984). These researchers were also unable to improve phytate-P utilization by including a yeast phytase in the maize-soya-bean meal diet in the balance studies and feeding trials with piglets.

Theoretically, the $\mathrm{P}$ content of feeds originating from plant materials should be sufficient to meet the requirements of poultry and pigs. The objectives of the present study were: (1) To further characterize the effects of phytase in vitro. The $\mathrm{pH}$ optimum of the enzyme was determined as well as the efficacy of the enzyme in liquid feed and feedstuffs such as soyabean meal and maize. In addition the resistance of the enzyme to pelleting was determined. (2) To verify and extend the results of Nelson et al. (1971). Availability trials were carried out with broilers receiving diets containing phytase. (3) To show whether the same enzyme preparation would be effective both in broilers and pigs. Digestibility trials were carried out with fistulated pigs receiving diets containing the same enzyme preparation as applied for the experiments with broilers.

\section{MATERIALS}

Enzyme production

Organism and growth conditions. Aspergillus ficuum strain NRRL 3135 was obtained from the Northern Region Research Laboratory, USDA, 1815 North University Street, Peoria, Illinois, USA. Fungal spore preparations were made following standard techniques. Spores and subsequently cells were transferred through a series of batch fermentations in Erlenmeyer flasks to a 10 litre fermentor. After growth in batch culture contents of this fermentor were used as inoculum for a final 500 litre batch fermentation.

Media used contained (g/1): maize starch (BDH Chemicals Ltd, Poole, Dorset) 91, glucose. $1 \mathrm{H}_{2} \mathrm{O} 38, \mathrm{MgSO}_{4} .7 \mathrm{H}_{2} \mathrm{O} 0-6 . \mathrm{KC} 10-6, \mathrm{FeSO}_{4} .7 \mathrm{H}_{2} \mathrm{O} 0-2, \mathrm{KNO}_{3}$ 12. The $\mathrm{pH}$ was maintained at 4-6 \pm -3 by automatic titration with either $4 \mathrm{M}$-sodium hydroxide or $4 \mathrm{M}$ sulphuric acid.

Cells were grown at $28^{\circ}$ at an automatically controlled dissolved oxygen concentration of $25 \%$ air saturation. Phytase production reached a maximum level after $10 \mathrm{~d}$ of fermentation.

Downstream processing. Fermentation broth was subjected to filtration followed by germ-free filtration. Phytase and other proteins were precipitated from the filtrate by adding acetone to a final volume of $600 \mathrm{ml} / 1$ under continuous stirring. The precipitate was dried in a vacuum at $35^{\circ}$. After grinding the dry powder, the enzyme product was used as such for application experiments.

\section{Phytic acid}

Phytic acid was obtained from Sigma (St Louis, MO). The batch was found to contain $150 \mathrm{~g}$ water $/ \mathrm{kg}$. The other reagents used were of analytical grade and were obtained from Merck (Darmstadt, West Germany). 
PHOSPHORUS AVAILABILITY AND MICROBIAL PHYTASE

Table 1. Composition of basal diet in experiments with broilers

\begin{tabular}{|c|c|}
\hline Ingredients & Contents $(\mathrm{g} / \mathrm{kg})$ \\
\hline Yellow maize & 280 \\
\hline Sorghum (low tannin) & 200 \\
\hline Sunflower-seed meal (solvent extracted) & 80 \\
\hline Soya-bean meal (solvent extracted, $488 \mathrm{~g}$ protein $/ \mathrm{kg}$ ) & 350 \\
\hline Soya-bean oil & $68-5$ \\
\hline Vitamins* & 5 \\
\hline Minerals* & 15 \\
\hline Limestone & 1 \\
\hline Synthetic methionine & 1 \\
\hline Chromic oxide & $0-5$ \\
\hline Total & 1001 \\
\hline Metabolizable energy $(\mathrm{MJ} / \mathrm{kg})$ & 131 \\
\hline Lysine & $12-9$ \\
\hline Methionine + cystine & $9 \cdot 1$ \\
\hline Calcium & $60(60,6-6) \mathrm{t}$ \\
\hline Total phosphorus & $4-5(4-7,4-7) \mathrm{t}$ \\
\hline Organic phytate-P & $3-0(3-1,3-1) \mathrm{t}$ \\
\hline
\end{tabular}

* Amount supplied (mg/kg diet): 3-6 retinol, 0-05 cholecalciferol, 5 vitamin E, $1-5$ vitamin $\mathrm{K}_{3}$, I thiamin, 5 riboflavin, 1 pyridoxine, 30 nicotinic acid, 7-5 D-pantothenic acid, 0015 vitamin $\mathrm{B}_{12}, 0-5$ folic acid, 350 choline chloride, 75 ethoxyquin, 9-5 $\mathrm{g} \mathrm{CaCO}_{3}, 2-5 \mathrm{~g} \mathrm{NaCl}, 0-26 \mathrm{~g} \mathrm{FeSO}_{4}, 0-24 \mathrm{~g} \mathrm{MnSO}, 45 \mathrm{mg} \mathrm{CuSO}, 60 \mathrm{mg} \mathrm{ZnSO}_{4}$, $105 \mathrm{mg}$ KI mixture.

f Values in parentheses were analysed for Expts 1 and 2 respectively.

\section{Diet content and pelleting}

Two experiments were carried out to study the effects of microbial phytase on $\mathrm{P}$ availability of feeds in broilers. The composition of the basal broiler diet is given in Table 1.

Control diets without the addition of phytase were used and these contained the following amounts $(\mathrm{g} / \mathrm{kg})$ of $\mathrm{Ca}$, total $\mathrm{P}$ and phytate-P respectively: diet $1,60,4-5,3 \cdot 0$; diet 2, 7-5, 60, 30; diet 3,90, 75, 30. No graded feed phosphate was added to diet 1 (basal diet). $\mathrm{Ca}$ and $\mathrm{P}$ from a mixture of anhydrous dicalcium phosphate and monoammonium phosphate $(5: 1, w / w)$ were added to diets 2 and 3 . All experimental diets were obtained by additions to the basal diet (diet 1).

In experiment 1 the optimum of the phytase dose was studied by adding 250, 500, 750, 1000 and 1500 units phytase/kg to the basal diet. A second experiment was performed to examine the effect of a dose higher than 1500 units phytase $/ \mathrm{kg}$ on $\mathrm{P}$ availability, growth rate and feed conversion ratio in broilers. To the basal diet were added 375, 750, 1500 or 2000 units phytase $/ \mathrm{kg}$.

In an experiment with pigs, two diets (Table 2) were used because the effect of phytase in vivo may differ with the type of diet. The first diet was based on maize and solventextracted soya-bean meal; the second diet was more like a practical diet, as used in The Netherlands, containing mainly tapioca meal and hominy feed. Limestone was added to the feeds to provide $55 \mathrm{~g} \mathrm{Ca} / \mathrm{kg}$ diet. To one part of both diets 1000 units phytase $/ \mathrm{kg}$ diet were added after which the diets were stored at $4^{\circ}$. The diets were offered twice daily in a meal form and were not pelleted.

The major components of the liquid feed for pigs, used for the in vitro experiment, were $(\mathrm{g} / \mathrm{kg})$ tapioca 400 , maize-gluten-feed meal 150, peas (Pisum sativum) 120 and solventextracted soya-bean meal 90 . The feed also contained $(\mathrm{g} / \mathrm{kg})$ : Ca $64, \mathrm{P} 5 \cdot 1$, phytate 2-7, dry matter 300-350. The $\mathrm{pH}$ of the mixture was 5-5 at the beginning of the incubation. 
Table 2. Composition of the diets for pigs $(\mathrm{g} / \mathrm{kg})$

\begin{tabular}{|c|c|c|c|c|}
\hline & \multicolumn{2}{|c|}{$\begin{array}{l}\text { Maize soya- } \\
\text { bean meal }\end{array}$} & \multicolumn{2}{|c|}{ Practical } \\
\hline Maize & \multicolumn{2}{|c|}{$859-5$} & \multicolumn{2}{|c|}{-} \\
\hline $\begin{array}{l}\text { Soya-bean meal (solvent } \\
\text { extracted; crude fibre }<3-5 \% \text { ) }\end{array}$ & \multicolumn{2}{|c|}{$124 \mathrm{fi}$} & \multicolumn{2}{|c|}{$124-6$} \\
\hline Tapioca meal & \multicolumn{2}{|c|}{-} & \multicolumn{2}{|c|}{$421-0$} \\
\hline Hominy feed USA & \multicolumn{2}{|c|}{ - } & \multicolumn{2}{|c|}{ 3361) } \\
\hline $\begin{array}{l}\text { Sunflower-seed meal } \\
\text { (solvent extracted) }\end{array}$ & \multicolumn{2}{|c|}{-} & \multicolumn{2}{|c|}{$80-0$} \\
\hline Soya-hcan oil & \multicolumn{2}{|c|}{ - } & \multicolumn{2}{|c|}{260} \\
\hline Limestone & \multirow{2}{*}{\multicolumn{2}{|c|}{$\begin{array}{r}11-8 \\
4-1\end{array}$}} & \multicolumn{2}{|c|}{83} \\
\hline Minerals and vitamins* & & & & 41 \\
\hline Total & \multicolumn{2}{|c|}{1000} & \multicolumn{2}{|c|}{1000} \\
\hline Phytasc & - & + & - & 4 \\
\hline Dry matter & $\$ 63$ & 863 & $\mathrm{KS} 2$ & 882 \\
\hline Ash & 35 & 35 & 65 & 66 \\
\hline $\begin{array}{l}\text { Crude protein } \\
\text { (nitrogen x 6-25) }\end{array}$ & 136 & 136 & 158 & 156 \\
\hline Crude fat & 34 & 32 & 47 & 47 \\
\hline Crude libre & 25 & 27 & 64 & 66 \\
\hline Calcium & $5-2$ & $5-0$ & $5-6$ & $5-7$ \\
\hline Magnesium & 15 & 15 & $2-5$ & $2-5$ \\
\hline Phosphorus & 3-3 & $3-3$ & 4) & 41 \\
\hline Potassium & 60 & 59 & 100 & 100 \\
\hline Phylic acid & $5-6$ & $8-5$ & $8-6$ & K4 \\
\hline $\mathrm{IP}_{\mathrm{S}}$ & $1-5$ & $1-7$ & $2-4$ & $2-6$ \\
\hline IP, & $1-2$ & $1-2$ & $1-6$ & $1-\mathrm{fi}$ \\
\hline
\end{tabular}

$\mathrm{JP}_{6}$, myo-inosiml pentakispriosphale; $1 \mathrm{P}_{\text {, }}$, myo-inosilol lelrakisphospliale.

'Amount supplied (mg/kg diet): 2-4 retinol. 004 cholecalciferol, B vitamin E, 4 riboflavin. 20 nicotinic acid. 8 panlothenic acid, 0-02 vitamin $\mathrm{B}, . .2125$ cholinc chloride. 125 antioxidant, 2-5 g NaCl, $043 \mathrm{~g} \mathrm{FeSO}, 50 \mathrm{mg} \mathrm{MnO}$, $155 \mathrm{mg} \mathrm{ZnSO}$. $40 \mathrm{mg} \mathrm{CuSO}$, 2 mg Kl, $001 \mathrm{mg} \mathrm{Se}$.

The pelleting experiments were performed on a CPM pelleting press (type CL 3; California Pellet Mill Corp., Crawfordsville, IN). The production capacity of this monoroll press is $200 \mathrm{~kg} / \mathrm{h}$. The pellets had a $5 \mathrm{~mm}$ diameter. The meal was common pig feed. The meal was heated with sleam to a temperature of 50 or $65^{\circ}$ before pelleting.

\section{METHODS}

Extraction and analysis of phytic acid and other inositol phosphates

The chymus and feed samples were freeze-dried and ground over a $0-5 \mathrm{~mm}$ sieve.

Feed samples were taken as such and about $2 \mathrm{~g}$ of each sample were accurately weighed and shaken with $20 \mathrm{ml} 0-8 \mathrm{M}$-hydrochloric acid for $2 \mathrm{~h}$ at room temperature. The slurry was centrifuged at $3000 \mathrm{rcv} . / \mathrm{min}$ (1800\#) for $10 \mathrm{~min}$. The supernatant fraction was separated by decantation and filtered over a paper filter.

The filtrate $(1-0 \mathrm{ml})$ was mixed in a $10 \mathrm{ml}$ volumetric flask with $0-25 \mathrm{ml} 2-8 \mathrm{M}-\mathrm{NaOH}$, $0-75 \mathrm{ml}$ of a solution of sodium acetate $(167 \mathrm{~g} / \mathrm{l})$ and $10 \mathrm{ml}$ EDTA solution $(40 \mathrm{~g} / 1$, adjusted to $\mathrm{pH} 6$ with $2 \mathrm{H} \mathrm{M}-\mathrm{NaOH}$ ), The mixture was allowed to stand at room temperature for $15 \mathrm{~min}$. The contents of the volumetric flask were made to volume with distilled water. 
The resulting mixture had a $\mathrm{pH}$ of about 6 . If necessary, the solution can further be diluted with sodium acetate solution $(15 \mathrm{~g} / 1, \mathrm{pH} 6)$. After filtration through a Millipore filter (0-45 micrometer) $50 / / \mathrm{I}$ of the solution were injected onto the column of the liquid chromatograph.

Analysis of myo-inositol pentakisphosphate $\left(\mathrm{IP}_{5}\right)$ and tetrakisphosphate (IPJ was performed according to Phillippy \& Johnston (1985), but for $\mathrm{IP}_{5} 0-08 \mathrm{M}-\mathrm{HNO}_{3}$ was used and for $\mathrm{IP}_{4} 006 \mathrm{M}-\mathrm{HNO}_{3}$ was used.

\section{Assays for phytase and phosphate}

Phytase activity. The assay is based on the production of free phosphate from phytate. The activity was determined in (a) enzyme preparations, (b) feed supplemented with phytase, and (c) contents of the gastrointestinal tract. Assays were carried out at $40^{\circ}$ in a shaking water-bath. The reaction was initiated by adding a 0-1 M-sodium acetate buffer adjusted to $\mathrm{pH}$ 5-5 and containing phytic acid at a final concentration of $1 \mathrm{~g} / 1$. A time-course of $60 \mathrm{~min}$ was taken by terminating the reaction after 15,30 and 60 min by adding $6 \mathrm{M}-\mathrm{HC} 1$ to a final concentration of $1 \mathrm{M}$. Samples to which $\mathrm{HC} 1$ had been added before the addition of phytic acid served as a blank for the contents of free phosphate.

After termination of the reaction samples were centrifuged for $10 \mathrm{~min}$ at $1800^{\wedge}$. The amounts of free phosphate were determined in the clear supernatant fractions as described below. Activities were calculated from time-intervals during which activity was linear with time. One unit of phytase is the activity that liberates $1 / / \mathrm{mol}$ phosphate from phytic acid in $1 \mathrm{~min}$.

Determination of free phosphate. Free phosphate was determined by means of an AutoAnalyzer method, using a Technicon AutoAnalyzer II. A sample from an in vitro experiment was filtered and $10 \mathrm{ml}$ of the filtrate was mixed with $90 \mathrm{ml} 1-2 \mathrm{M}-\mathrm{HCl}$. Part of the mixture was injected into the AutoAnalyzer. The reagent used for the analysis of phosphate was the molybdovanadate reagent, described by Olsen \& Sommers (1982). The preparation of the reagent was somewhat modified. Solution A: $50 \mathrm{~g}$ ammonium paramolybdate $\left(\left(\mathrm{NH}_{4}\right)_{\mathrm{s}} \mathrm{Mo}_{7} \mathrm{O}_{24} .4 \mathrm{H}, \mathrm{O}\right)$ were dissolved in $800 \mathrm{ml}$ warm distilled water. The solution was cooled to room temperature and diluted to 1 litre with distilled water. Solution B: $2-5 \mathrm{~g}$ ammonium metavanadate $\left(\mathrm{NH}_{4} \mathrm{VO}_{3}\right)$ were dissolved in $500 \mathrm{ml}$ boiling distilled water. The solution was cooled and $20 \mathrm{ml}$ concentrated nitric acid were added. The mixture was diluted to 1 litre with distilled water. Solution C: $333 \mathrm{ml}$ concentrated $\mathrm{HNO}_{3}$ were carefully added to $600 \mathrm{ml}$ distilled water. The mixture was diluted to 1 litre with distilled water. Solution A was poured into solution B. Solution C was added to the mixture of A and $\mathrm{B}$.

The acid diluent for the AutoAnalyzer was prepared by adding $40 \mathrm{ml}$ of concentrated sulphuric acid to $800 \mathrm{ml}$ of distilled water and the mixture was diluted to 1 litre with distilled water. To the acid diluent and to the water a detergent (aerosol) was added at a concentration of $0-5 \mathrm{ml} / 1$. The AutoAnalyzer was calibrated by using standard solutions in the range of $5-30 \mathrm{mg} \mathrm{P} / \mathrm{l}$.

Miscellaneous analyses. Faeces and droppings were air- and freeze-dried and analysed for dry matter, Ca, P and chromium (Jongbloed, 1987). A composite sample of feeds was made, freeze-dried and analysed for dry matter, Ca, P, phytic acid (Oshima et al. 1964) and phytase activity. 


\section{Liquid chromatography}

Liquid chromatographic system. The chromatograph consisted of two modified LDCMilton Roy minipumps from Biotronik (Munich, West Germany). One pump was used for the eluent and one for the reagent. The single-headed pumps were provided with pulsedamping devices as are commonly used in automated amino acid analysers. The anionexchange column used was a Dionex HPIC AS-3 (5-0 mm i.d. x $250 \mathrm{~mm}$ ). A Dionex HPIC AG-3 guard column was employed. The injector had been supplied by Pharmacia (Uppsala, Sweden). The injection volume was 50 //I. The reaction coil was made of Teflon tubing with an internal diameter of $0-3 \mathrm{~mm}$ and a length of $3 \mathrm{~m}$. It was kept in an oil bath at $50^{\circ}$. A variable u.v./visual detector $(300 \mathrm{~nm})$ of Kratos was used.

Liquid chromatography conditions. Eluent A was an aqueous solution of sodium nitrate and EDTA. Sodium nitrate (2-5 g) was dissolved in 1 litre water containing 0-5 $\mathrm{ml}$ of an EDTA solution $(40 \mathrm{~g} / 1)$. The $\mathrm{pH}$ was adjusted to $6-0$ with $2-8 \mathrm{M}-\mathrm{NaOH}$. Eluent $\mathrm{B}$ was an aqueous solution of 0-1 M-sodium nitrate adjusted to $\mathrm{pH}$ 3-5 with eluent $\mathrm{C}$. Eluent $\mathrm{C}$ was an aqueous solution of nitric acid $(9 \mathrm{ml} / 1)$.

The elution programme was: eluent $\mathrm{A}$ for $5 \mathrm{~min}$, eluent $\mathrm{B}$ for $5 \mathrm{~min}$, eluent $\mathrm{C}$ for $13 \mathrm{~min}$ and eluent $\mathrm{A}$ for $7 \mathrm{~min}$. The eluent flow was $1 \mathrm{ml} / \mathrm{min}$. The postcolumn reagent was a solution of 2-2 g iron(III)perchlorate nonahydrate and 12-8 ml perchloric acid (ml/1) in 1-0 litre water. The reagent was stored in a brown flask. A flow-rate of $0-5 \mathrm{ml} / \mathrm{min}$ was applied.

\section{EXPERIMENTAL PROCEDURES}

\section{In vitro degradation}

The degradation of the phytate in feeds by the microbial phytase was studied in experiments in vitro. The enzyme was added to ground maize and to a sample of ground soya-bean meal. The degradation of phytate was studied at two $\mathrm{pH}$ values (2-5 and 5-5) and at $40^{\circ}$. Therefore, the ground feedstuffs $(4 \mathrm{~g})$ were mixed with $8 \mathrm{ml}$ buffer solution $(0-1$ triacetate buffer solution resulting in a $\mathrm{pH}$ of 5-5, or 0-1 $\mathrm{M}$-citrate buffer solution resulting in a $\mathrm{pH}$ of 2-5). A series of pelleting experiments were performed with feed to which microbial phytase had been added. As part of the pelleting process, the meal was steam-heated to $50^{\circ}$ or $65^{\circ}$. The energy uptake by the press was chosen Mow ${ }^{1}$ or "high'.

\section{Experiments with broilers}

Two experiments were carried out to study the effects of microbial phytase on P availability of feeds in broilers.

Male broiler chicks (1-d-old; Hybro) were housed in two-tier battery cages (0-45 nr'). The ambient temperature was $32^{\circ}$ during the first $2 \mathrm{~d}$ and was decreased by $4^{\circ}$ in the first week. Every following week the temperature was decreased by $2^{\circ}$. Broilers were reared in a $1 \mathrm{~h}$ light and $3 \mathrm{~h}$ dark regimen.

Birds were vaccinated against Newcastle Disease at $1 \mathrm{~d}$ of age using Clone 30 vaccine. During the experiments the broilers were fed on the experimental diets ad lib. (Table 1). The diets were not pelleted.

Growth and feed conversion ratios were measured during the experimental periods. Apparent availability of total $P$ was measured in a $3 \mathrm{~d}$ period, during which feed consumption was measured as dry matter intake and excreta were collected quantitatively. Apparent availability of $\mathrm{P}$ is defined as the difference between intake of $\mathrm{P}$ and excretion of $\mathrm{P}$ with the excreta.

Post-mortem examination was carried out on all broilers which died or were obviously ill, to determine the cause of death or illness. 


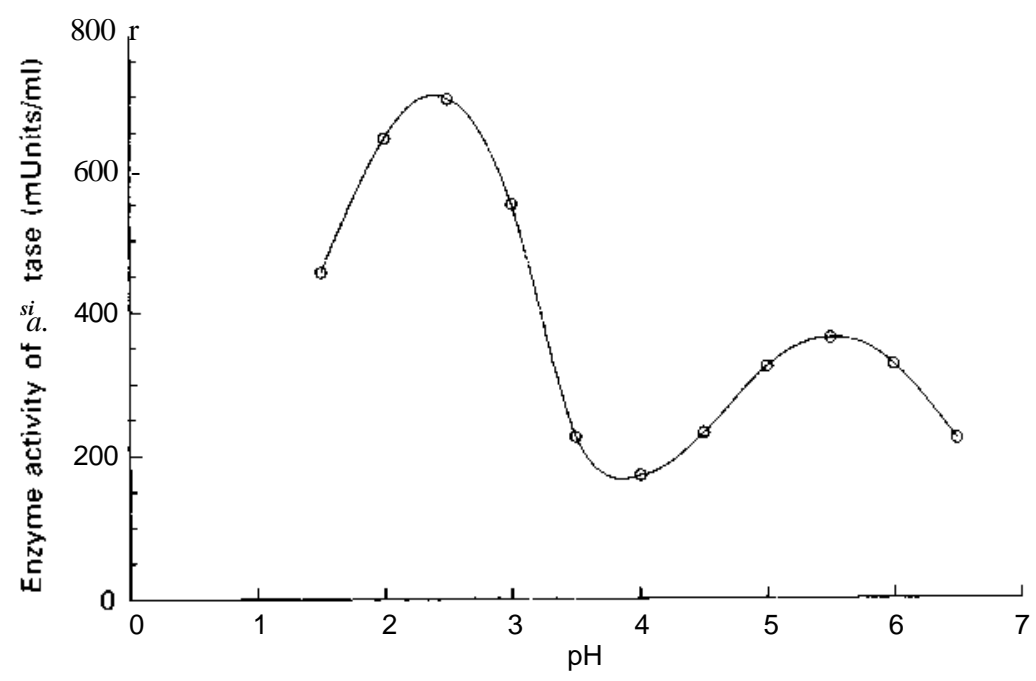

Fig. I. The activity of crude microbial phytasc determined at several $\mathrm{pH}$ values.

Expt I. The experiment was carried out with 176 broilers in sixteen battery cages (eleven per battery cage) until the age of $24 \mathrm{~d}$. The eight treatments (diets) were replicated two times and were assigned randomly to the cages within each tier. The availability of $\mathrm{P}$ was measured from 21 to $24 \mathrm{~d}$ of age.

Expt 2. The experiment was carried out with 168 broilers in fourteen battery cages (twelve per battery cage) until the age of 4 weeks. The seven treatments (diets) were replicated twice and were assigned randomly to the cages within each tier. The availability of $\mathrm{P}$ was measured from 21 to $24 \mathrm{~d}$ of age.

\section{Experiment with pigs}

In this experiment six pigs of the Large White breed were used in the live weight range of $35-70 \mathrm{~kg}$. Throughout the experiment the animals were housed individually in pens of $2-00 \times 1-45 \mathrm{~m}$ and were not tied up. At a live weight of $37 \mathrm{~kg}$ these animals were fitted with two simple T-cannulas, one approximately $180 \mathrm{~mm}$ beyond the pylorus and one $200 \mathrm{~mm}$ proximal to the ileo-caecal junction. In the animals the apparent digestibilities of $\mathrm{P}$ and $\mathrm{Ca}$ were measured using Cr-NDR (chromium absorbed to neutral detergent residue) as an indigestible marker. The amount of Cr-NDR was weighed out separately (4-0 $\mathrm{g} / \mathrm{kg}$ feed) and added just before feeding in the trough and mixed with feed and water. The water was added to the feed just before feeding time in the proportions 2-5:1 (w/w). To avoid feed refusals the amount of feed supplied was 2-3 times maintenance requirement $=293 \mathrm{~kJ}$ net energy for fattening $/ \mathrm{kg}$ body-weight ${ }^{075}$ or $418 \mathrm{~kJ}$ metabolizable energy $/ \mathrm{kg}$ body-weight ${ }^{0,75}$.

For the experiment a cross-over design was used. A maize -soya-bean meal diet without and with phytase was supplied in two periods to two groups of three pigs. The mean bodyweight in both periods was 46 and $52 \mathrm{~kg}$ respectively. Afterwards a more practical diet was supplied in the same way to the same pigs. The mean body-weight was 60 and $66 \mathrm{~kg}$ respectively. The collection of faeces started $8 \mathrm{~d}$ after change of maize-soya-bean meal diets and $9 \mathrm{~d}$ after changing to the practical diet. At 4 weeks after surgery the first collection period was started. During two consecutive days per animal, grab samples of fresh faeces were gathered and added together. 


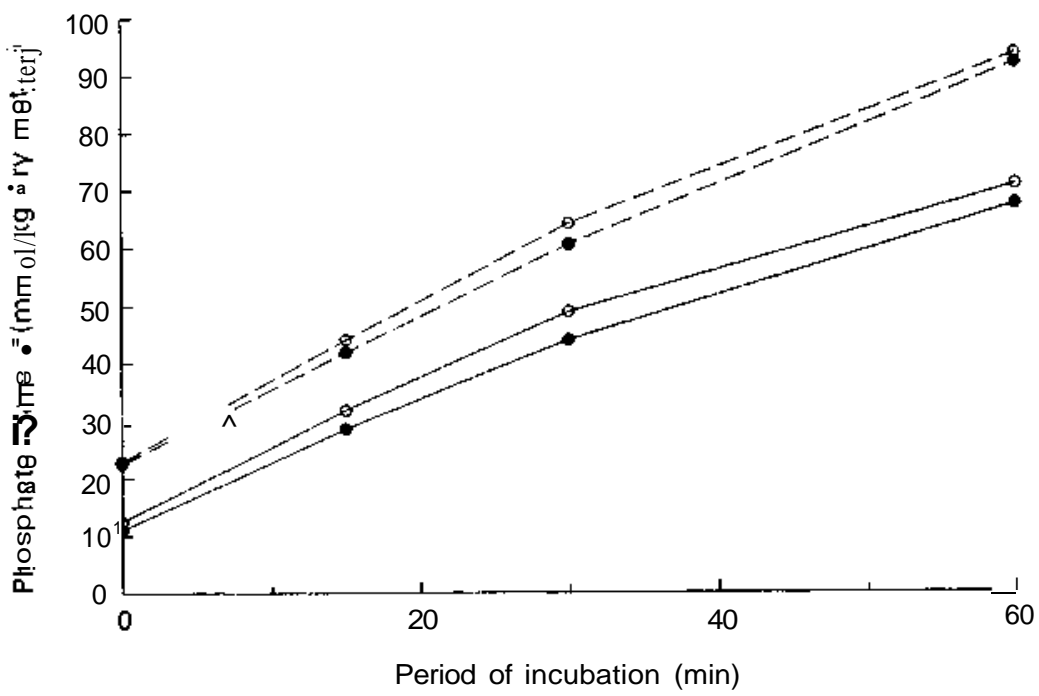

Fig. 2. Increase in the amount of free phosphate from the degradation of phytatc in samples of maize and soyabean meal by microbial phytase $(1000$ units $/ \mathrm{kg})$. Values as a result of period of incubation and $\mathrm{pH}$. Maize: $(\bullet-\bullet) \mathrm{pH} 2-5$; $(\mathrm{O} \longrightarrow \mathrm{O}) \mathrm{pH} 5-5$; soya-bean: $(\mathrm{O}-\mathrm{O}) \mathrm{pH} 2-5 ;(\bullet-\bullet, \mathrm{pH} 5-5$.

\section{Statistical analyses}

The experimental data of the broiler experiments were examined by analyses of variance using non-linear regression models, which included:

model 1 (Expts 1 and 2)

$$
Y_{\mathrm{i}, \mathrm{i}}=N+T_{\mathrm{i}}+B l_{\mathrm{j}}+e_{\mathrm{ij}}
$$

model 2 (Expts 1 and 2; diets 1, 4, 5, 6 etc.)

$$
Y=A+B R^{x}+e,
$$

where $N$ is the mean level, $T$ is the effect of treatment, $B l$ is the effect of tier, $e$ is the error contribution with average 0 and variance $r r^{2}, A, B$ and $R$ are parameters $(0<R<$ 1 ) and $x$ is the dose of phytase (100 units $/ \mathrm{kg}$ ).

The results obtained with the pigs were analysed using analysis of variance according to the following model:

$$
Y_{\mathrm{ijk}}=N+A_{1}+P_{1}+T_{\mathrm{k}}+e_{\mathrm{ijk}}
$$

where $A$ is the effect of animal and $P$ is the effect of period. There was no evidence of $P \times T$ interaction.

\section{RESULTS}

In vitro experiments

The activity of the crude microbial enzyme was determined at several $\mathrm{pH}$ values. The activities found are shown in Fig. 1. The enzyme showed maximal activities at pH 5-5 and at $\mathrm{pH}$ 2-5. 


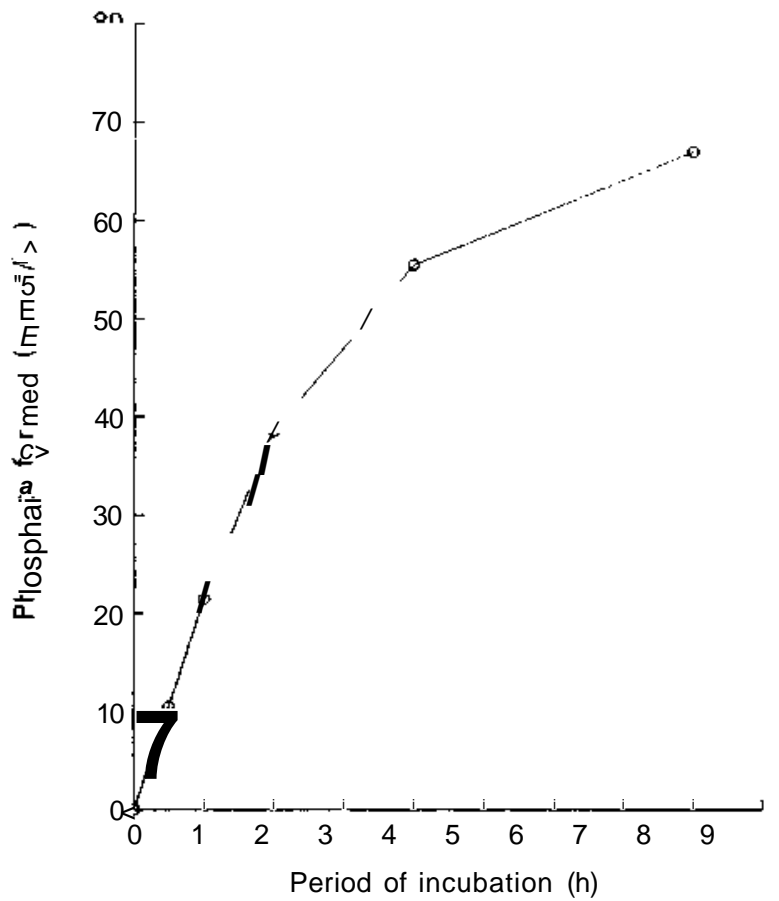

Fig. 3. Increase in the amount of free phosphate from the in vitro degradation of phytate in liquid feed for pigs by microbial phytase (1000 units/kg feed) at room temperature. Values as a result of period of incubation.

Table 3. Phytase activity of pelleted feed produced under various pelleting, conditions

\begin{tabular}{|c|c|c|c|c|}
\hline $\begin{array}{l}\text { Temperature } \\
\text { of the } \\
\text { meal before } \\
\text { the press } \\
\left({ }^{\circ}\right)\end{array}$ & $\begin{array}{l}\text { Temperature } \\
\text { of the } \\
\text { pellets } \\
\text { after } \\
\text { pelleting } \\
\text { O }\end{array}$ & $\begin{array}{c}\text { Energy } \\
\text { input } \\
(\mathrm{W} \text { att } \mathrm{h} / \mathrm{kg})\end{array}$ & $\begin{array}{c}\text { Phytase } \\
\text { activity } \\
\text { in the } \\
\text { pellets } \\
\text { (units } / \mathrm{kg} \text { )* }\end{array}$ & $\begin{array}{c}\text { Remaining } \\
\text { activity } \\
(\%)\end{array}$ \\
\hline 50 & 78 & 20 & 240 & 96 \\
\hline 50 & 81 & 25 & 234 & 94 \\
\hline 65 & 84 & 17 & 208 & 83 \\
\hline 65 & 87 & 23 & 115 & 46 \\
\hline
\end{tabular}

* The phytase activity of the meal before the pelleting process was 250 units $/ \mathrm{kg}$.

The degradation of the phytate in samples of soya-bean meal and in ground maize by the microbial phytase was studied in experiments in vitro. The results are shown in Fig. 2. The soya-bean meal contained 12-1 g phytic acid/kg dry matter. After complete hydrolysis of this phytic acid, $11 \mathrm{Ommol}$ free phosphate $/ \mathrm{kg}$ might be formed. About $93 \mathrm{mmol}$ free phosphate $/ \mathrm{kg}$ were formed after an incubation time of $1 \mathrm{~h}$ at $40^{\circ}$.

The maize contained 6-94 g phytic acid/kg dry matter. After a complete hydrolysis of the phytic acid, $63 \mathrm{mmol}$ free phosphate/kg might be formed. About $69 \mathrm{mmol}$ free phosphate/kg were found after an incubation of $1 \mathrm{~h}$. This suggests that the phytic acid had 
Table 4. Expt 1. The effect of microbial phytase on the apparent availability of total phosphorus and calcium, $P$ in manure and the performance of broilers*

\begin{tabular}{|c|c|c|c|c|c|c|c|c|c|c|c|}
\hline \multirow{2}{*}{$\begin{array}{l}\text { Diets } \\
\text { no. }\end{array}$} & \multirow{2}{*}{$\begin{array}{c}\mathrm{Ca} \\
(\mathrm{g} / \mathrm{kg})\end{array}$} & \multirow{2}{*}{$\begin{array}{c}\mathrm{P} \\
(\mathrm{g} / \mathrm{kg})\end{array}$} & \multirow{2}{*}{$\begin{array}{l}\text { Added } \\
\text { phytase } \\
\text { (units/kg) }\end{array}$} & \multicolumn{2}{|c|}{$\begin{array}{c}\text { Availability (\%) } \\
21-24 \mathrm{~d}\end{array}$} & \multirow{2}{*}{$\begin{array}{l}\text { Amount of } \mathrm{P} \\
\text { in manure }(\mathrm{g} / \mathrm{kg} \text { dry } \\
\text { matter feed intake })\end{array}$} & \multirow{2}{*}{$\begin{array}{l}\text { Growth } \\
0-2 \text { weeks } \\
\text { (g) }\end{array}$} & \multirow{2}{*}{$\begin{array}{c}\text { Feed conversion } \\
\text { ratio } \\
0-2 \text { weeks }\end{array}$} & \multirow{2}{*}{$\begin{array}{l}\text { Growth } \\
0 \cdot 24 \mathrm{~d} \\
(\mathrm{~g})\end{array}$} & \multirow{2}{*}{$\begin{array}{c}\text { Feed conversion } \\
\text { ratio } \\
0-24 \mathrm{~d}\end{array}$} & \multirow{2}{*}{$\begin{array}{l}y \\
0 \\
\mathbf{S}\end{array}$} \\
\hline & & & & $\mathrm{P}$ & $\mathrm{Ca}$ & & & & & & \\
\hline I & 6 & $4-5$ & 0 & $49-8^{\mathrm{a}}$ & $47-2^{\prime \prime}$ & $2-7^{\mathrm{a}}$ & $166^{\mathrm{a}}$ & $1 \cdot 69^{\mathrm{a}}$ & 338" & $1 \cdot 85^{\mathrm{a}}$ & If \\
\hline 2 & $7-5$ & 6 & 0 & $45-6$ & $48-9^{\mathrm{a}}$ & 3-8" & $247^{\text {"r }}$ & l. $48 "$ & $592^{\prime \prime \prime \prime}$ & 1•61" & $\frac{3}{0}$ \\
\hline 3 & 9 & $7-5$ & 0 & 44-6" & $46-9^{\mathrm{a}}$ & $4-9^{11}$ & $288^{\text {"e }}$ & l•38" & 683" & $1.55^{1 \mathrm{k \prime}}$ & \\
\hline 4 & 6 & $4-5$ & 250 & $56-5^{\prime \prime}$ & $57-1 "$ & 2-3" & $238^{\prime \prime}$ & l.46" & $566 "$ & ¡•59" & in \\
\hline 5 & 6 & $4-5$ & 500 & $59-6^{\text {cd }}$ & $59-3^{\mathrm{cc}}$ & 2. [de & $266^{\prime \prime \prime}$ & 1•40" & $623^{\mathrm{r}}$ & $1.56 \mathrm{mo}$ & $\therefore$ \\
\hline 6 & 6 & $4-5$ & 750 & $59-5^{\prime \prime} 1$ & $60-3^{n \mathrm{r}}$ & $2-1^{n f}$ & $293^{\mathrm{e}}$ & [.37" & $675^{\prime \prime}$ & 1.55"'" & $\vec{z}$ \\
\hline 7 & 6 & $4-5$ & 1000 & $62-5^{\prime \prime p}$ & 64-3"'" & $2-0^{\circ}$ & $291^{\circ}$ & l-38" & 690" & $1 \cdot 52^{\mathrm{i}}$ & \\
\hline 8 & 6 & $4-5$ & 1500 & $64-5^{\prime \prime}$ & $68-1 "$ & $1-9^{\prime \prime}$ & $298^{* 1}$ & l•34" & 733" & [.50" & $\stackrel{\odot}{\mathrm{H}}$ \\
\hline \multirow{3}{*}{\multicolumn{4}{|c|}{$\begin{array}{l}\text { Statistical significance } \\
\text { of difference: } P< \\
\text { SED }\end{array}$}} & & & & & & & & \\
\hline & & & & 0001 & $0-001$ & $0-001$ & 0001 & $0-01$ & 0001 & 0001 & 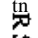 \\
\hline & & & & $1-46$ & $2-53$ & 0089 & $9-7$ & $0-064$ & 141 & $0-029$ & \\
\hline
\end{tabular}

SED, standard error of difference between two means.

* For details of diets, see Table

at) id Valuerseript letters were significantly different: $P<0-05$. 
Table 5. Expt 2. The effect of microbial phytase on the apparent availability of total phosphorus, $P$ in manure and the performance of broilers*

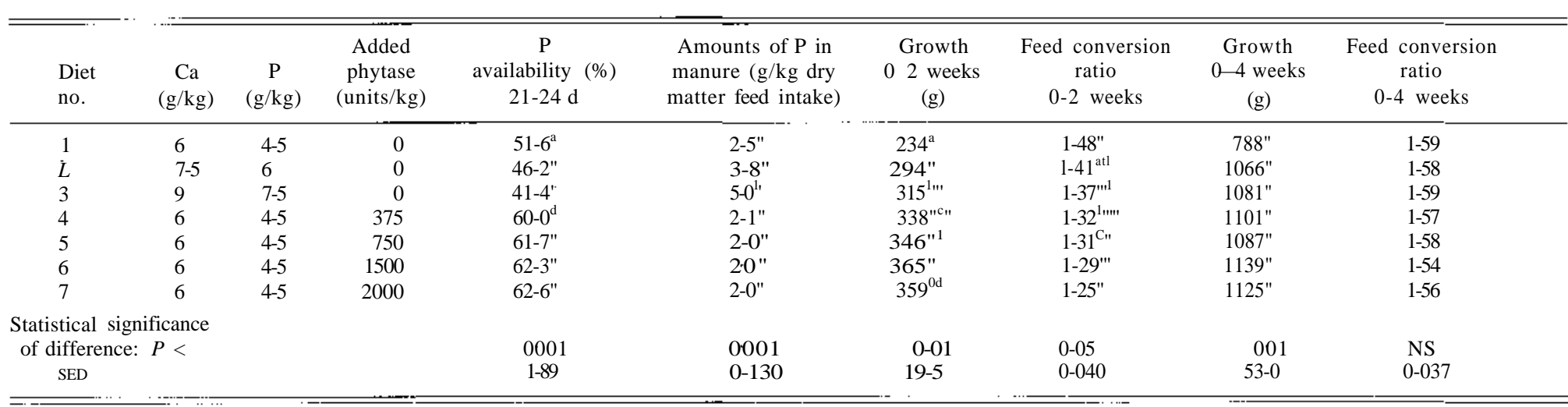

SED, standard error of differences between two means; NS, not significant.

For details of diets, see Table 1 .

D. i-ii Values within the same column with different superscript letters were significantly different. 
Table 6. Results of non-linear regression analysis in broiler experiments (Estimated values with their standard errors)

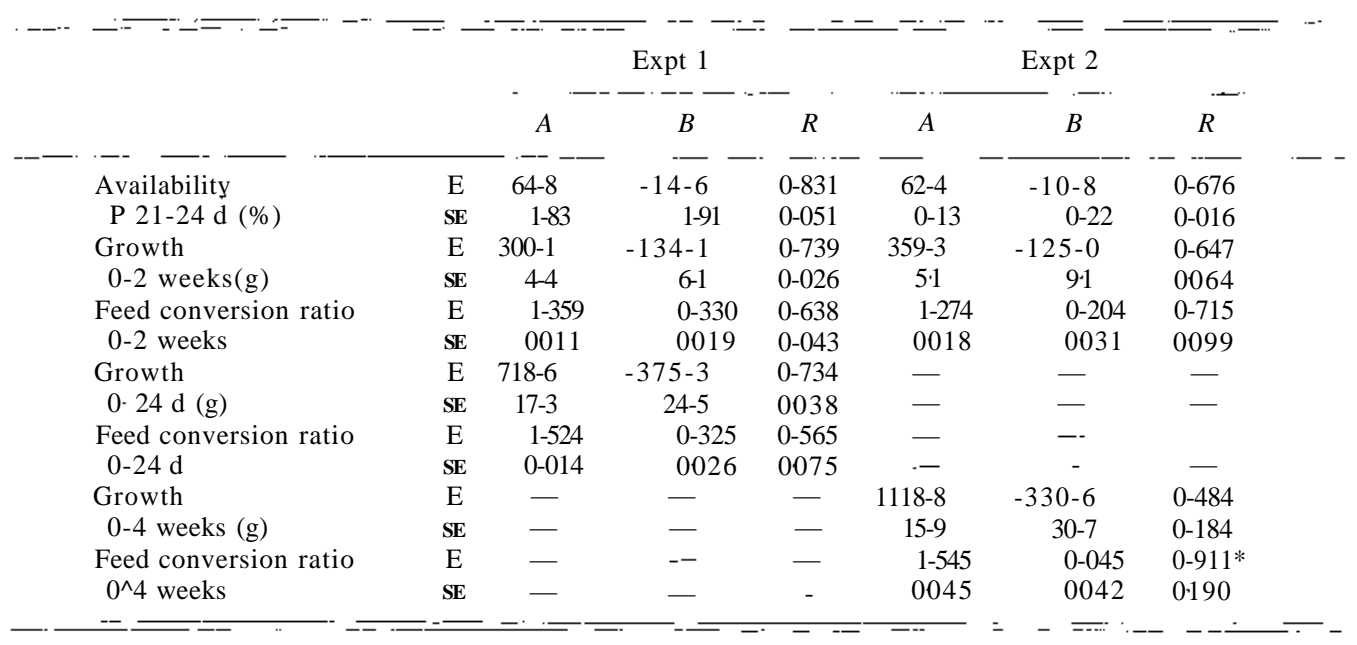

E, estimate of parameters $A, B$ and $R$ (for details, see p. 532).

* Non-linear regression line is not reliable, \% variance accounted for 28-6.

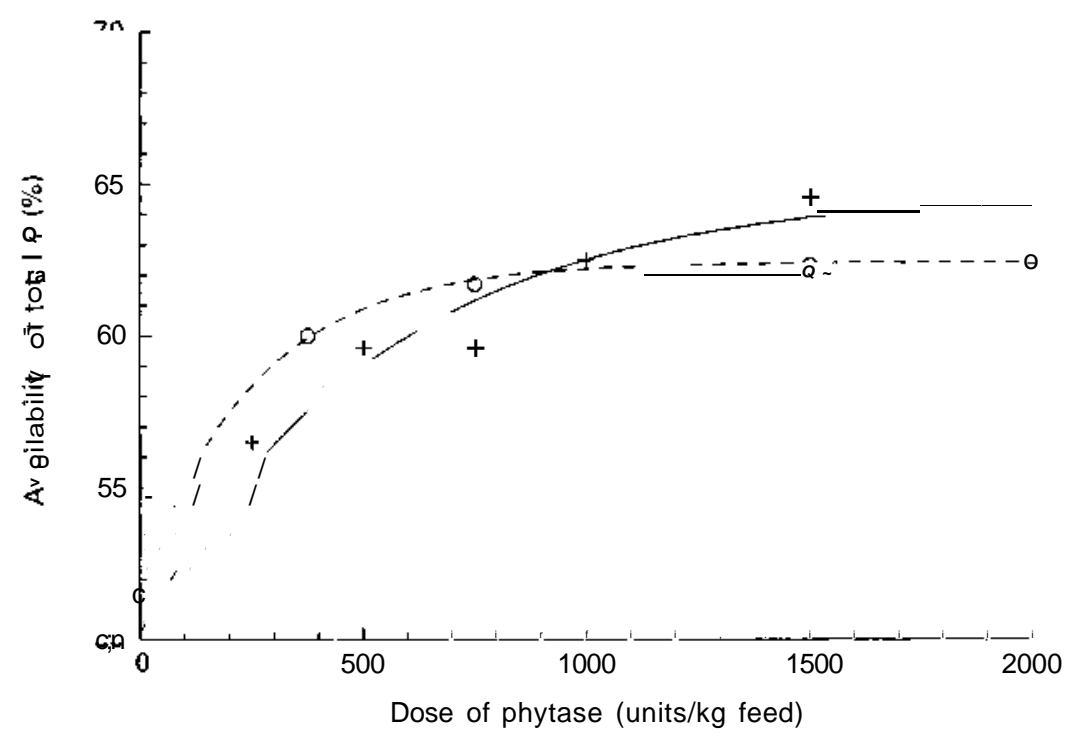

Fig. 4. Apparent availability of phosphorus in broiler diets with 0-45 phosphorus and various additions of phytase; result of non-linear regression analysis (+). Expt 1, 21-24 d; (O), Expt 2, 21-24 d.

been degraded completely, with some phosphate having been liberated from other phosphate sources by the crude enzyme preparation.

The application of phytase in liquid feed for pigs was studied in vitro at room temperature. The increase in the concentration of or/Ao-phosphate after the addition of 1000 units of microbial phytase/kg is shown in Fig. 3. The feed contained 7-3 g phytic 
$\mathrm{acid} / \mathrm{kg}$ dry matter. After complete hydrolysis of this phytic acid, 66-4 mmol free orthophosphate/kg might be formed. An increase of free phosphate of $66-8 \mathrm{mmol} / \mathrm{kg}$ was observed after the incubation for $8 \mathrm{~h}$. It may be concluded that the phytate-bound $\mathrm{P}$ was completely liberated. About $80 \%$ of the phytate-bound phosphate $(55-5 \mathrm{mmol} / \mathrm{kg}$ ) was liberated after $4 \mathrm{~h}$ of incubation.

The pelleting experiments with feed to which microbial phytase had been added showed significant inactivation of phytase activity when temperatures of the pellets after pelleting exceeded $84^{\circ}$ (Table 3).

\section{Broiler experiments}

The results of two experiments with broilers are given in the Tables 4-6 and Fig. 4. A low apparent availability of total $\mathrm{P}$ was measured with diet 1 (Tables 4 and 5). Addition of inorganic graded feed phosphate (and $\mathrm{Ca}$ ) to this basal diet decreased the apparent availability of $\mathrm{P}$ significantly. The apparent availability of $\mathrm{P}$ was significantly improved by adding different levels of microbial phytase. When the availability of $\mathrm{P}$ improved the availability of $\mathrm{Ca}$ increased (Table 4) and the amount of $\mathrm{P}$ in the droppings decreased. Both non-linear regression lines for apparent availability of total $\mathrm{P}$ are reliable since the percentage of variance accounted for 94-5 and 99-8 in Expts 1 and 2 respectively (Table 6). The standard error of the parameters in Expt 2 are much lower than those in Expt 1 due to a much smaller residual variance; no explanation for this could be found.

Fig. 4 shows that an almost maximum apparent $P$ availability in Expt 2 was obtained when 800 units microbial phytase $/ \mathrm{kg}$ feed were added; in Expt 1 a further increase of the apparent $\mathrm{P}$ availability was observed at doses exceeding 800 units $/ \mathrm{kg}$. However, the standard error in Expt 1 was much larger than that in Expt 2.

Growth rate and feed conversion ratio with the low-P diets with added microbial phytase were significantly improved, except for the feed conversion ratio from 0 to 4 weeks. Growth rate and feed conversion ratio of the broilers were dependent on the level of microbial phytase. A lower growth rate compared with control diet 3 was found with 250 units phytase/kg in Expt 1 (Table 4). In Expt 1 an improved growth rate compared with diet 2 was obtained with additions of 750,1000 or 1500 units microbial phytase $/ \mathrm{kg}$. During the period $0-24 \mathrm{~d}, 1500$ units phytase $/ \mathrm{kg}$ gave a significantly better growth compared with all the other groups (Table 4). In Expt 2 the best growth at 4 weeks of age was also obtained with 1500 units phytase $/ \mathrm{kg}$ (diet 6), although this was not significantly different from diets 2, 3, 4, 5 and 7 (Table 5). Table 4 shows that from 0 to $24 \mathrm{~d}$ in Expt 1, diets 7 and 8 (1000 and 1500 units phytase $/ \mathrm{kg}$ respectively) yielded a significantly improved feed conversion ratio compared with diets 1,2 and 4 ( 0 or 250 units phytase $/ \mathrm{kg}$ ). From 0 to 2 weeks in Expt 2 , additions of 750 units phytase or more improved the feed conversion ratio compared with diets 1 and 2 (Table 5). As can be seen in Tables 4 and 5, an increase in the level of phytase improved the feed conversion ratio. This is even more apparent from the non-linear regression lines. The non-linear regression lines of the growth rate and feed conversion ratio, with the exception of the feed conversion ratio line until 4 weeks of age, were reliable since the percentage of variance accounted for 91 -4-99-8 in both experiments (Table 6). This means that a higher dose of phytase in the diets improved both the growth rate and feed conversion ratio significantly.

Diet 1 caused a rather high mortality. No difference in mortality occurred between the various groups receiving the other diets. 
Table 7. Results of the digestibility trials with pigs

\begin{tabular}{|c|c|c|c|c|c|c|c|c|c|}
\hline \multirow[b]{2}{*}{$\begin{array}{l}\text { Microbial phytase... } \\
\ll \ldots\end{array}$} & \multicolumn{4}{|c|}{ Maize-soya-bean meal } & \multicolumn{5}{|c|}{ Practical } \\
\hline & $\overline{6}$ & $\begin{array}{l}+ \\
6\end{array}$ & SED & $\begin{array}{c}\text { Statistical } \\
\text { significance } \\
\text { of difference }\end{array}$ & $\overline{5}$ & $\begin{array}{l}+ \\
5\end{array}$ & SED & $\begin{array}{c}\text { Statistical } \\
\text { significance } \\
\text { of difference }\end{array}$ & \\
\hline \multicolumn{10}{|l|}{ Digestibility (\%) } \\
\hline DM & $85-2$ & $85-0$ & $1-6$ & NS & $81-0$ & $81-3$ & $0-1$ & NS & \\
\hline Phosphorus & 20 & 46 & $4-0$ & $* *$ & 34 & 56 & $1-6$ & $* * *$ & \\
\hline Calcium & 44 & 50 & $5-2$ & NS & 50 & 58 & 10 & $* *$ & \\
\hline$P$ in faeces $(g / k g D M)$ & 210 & $13-6$ & $1-3$ & $* *$ & $16-3$ & $10-9$ & $0-4$ & $* * *$ & \\
\hline $\mathrm{Ca}$ in faeces $(\mathrm{g} / \mathrm{kg} \mathrm{DM})$ & $22-8$ & $19-2$ & $1-3$ & $*$ & $17-4$ & $15-4$ & $0-4$ & $*$ & \\
\hline
\end{tabular}

SED, standard error of difference; DM, dry matter; NS, not significant $* P<0-05, * * P<0-01, * * * p<0-001$.

Pig experiment

One pig became feverish at about $60 \mathrm{~kg}$ live weight and refused feed occasionally. As the results obtained with this pig deviated considerably from those in the other animals, these were omitted from the final calculations.

As can be seen in Table 2, the chemical analyses in the two types of diet were nearly equal, except for the phytase activity. The effect of microbial phytase on the digestibility of dry matter and the apparent absorbability of $\mathrm{Ca}$ and $\mathrm{P}$ and on the $\mathrm{P}$ concentration in the faeces are given in Table 7. The addition of phytase to the diet had no effect on the digestibility of dry matter. The faecal concentration of $\mathrm{P}$ decreased by about $35 \%$ and the apparent absorbability of $\mathrm{P}$ improved substantially (twenty-four percentage units). There was a significant reduction $(P<005)$ in the faecal $\mathrm{Ca}$ concentration, but the apparent absorbability of $\mathrm{Ca}$ was increased significantly only in the practical diet.

\section{DISCUSSION \\ In vitro experiments}

The microbial phytase is active over a wide $\mathrm{pH}$ range (Fig. 1). This implies that the enzyme will be active in liquid pig feed having a $\mathrm{pH}$ of about 6 , as well as in the stomach of animals where the $\mathrm{pH}$ is between 2 and 5. The enzyme has no activity at $\mathrm{pH} 7$. Phytate in samples of maize and in soya-bean meal is easily degraded by added phytase at $\mathrm{pH} 2-5$ as well as at $\mathrm{pH} 55$ (Fig. 2). In a liquid compound feed for pigs similar results were obtained at a $\mathrm{pH}$ of 5-5 (Fig. 3). Metal ions like $\mathrm{Ca}$, magnesium, iron or zinc may form strong complexes with phytic acid (Wise, 1983) which have a poor solubility at higher $\mathrm{pH}$ values. Complexes of these metal ions with phytic acid might be less available for degradation by phytase. No indications for such a low solubility of phytate were obtained in the in vitro experiment of liquid pig feed with microbial phytase. This is rather surprising since animal feed usually contains a high level of divalent metal ions.

The results of the pelleting experiments are given in Table 3. A high energy input means that the shear during the pelleting process is high. Under these conditions many plant cells are crushed, which is favourable for the digestion process in animals. The effect of the shear on the phytase activity appears to be small; it is mainly the high temperature which results from the high energy input which will inactivate the enzyme.

The experiments make it clear that the thermal stability of the microbial enzyme is good. The enzyme will remain stable if the proper pelleting conditions are chosen. 


\section{Broiler experiments}

The low apparent availability of $\mathrm{P}$ in broilers fed on phytase-free diets (diet 1) can be explained by the high level of phytate-P that is not available for simple-stomached animals. Additions of microbial phytase to diet 1 improved the availability of $\mathrm{P}$ significantly. The amount of $\mathrm{P}$ in the droppings is, therefore, significantly lowered. As the availability of $\mathrm{P}$ increases, the availability of $\mathrm{Ca}$ increases, since both are deposited in the bone at the same time. Possibly the $\mathrm{Ca}$ content in the diets with microbial phytase was too low to achieve a maximum availability of $\mathrm{P}$. It was expected from experiments reported by Nelson et al. (1971) that growth rate and feed conversion ratio of birds given diets with sufficient microbial phytase would be comparable with those given control diets (2 and 3) which contained supplemental graded feed phosphate (and $\mathrm{Ca}$ ).

In our experiments growth rate and feed conversion ratio were improved by increasing the level of phytase (Tables 4, 5 and 6); although there were differences in level between both experiments at the same age, comparable results were obtained.

From these two experiments with broilers it may be concluded that an addition of 1000 units microbial phytase to feed provides levels of performance which are as good as or better than those with feed supplemented with phosphate. The improved growth rate and feed conversion ratio with higher levels of phytase might be explained by (a) release of minerals and trace elements from complexes with phytic acid, or (b) by utilization of inositol by the animals after hydrolysis of phytic acid to inositol and inorganic P, or (c) a possible increased starch digestibility as suggested by Knuckles \& Betschart (1987) and Cawley \& Mitchell (1968), or combinations of a, b and c. An improved feed conversion ratio till 2 weeks of age was obtained with even lower doses of phytase. Why the feed conversion ratio is no longer significantly improved at 4 weeks of age is not clear. A lower requirement of $\mathrm{P}$ at 4 weeks of age compared with 2 weeks of age and an adaptation of the birds to utilize more phytate-P in critical circumstances might explain these findings. This aspect warrants further research. When the level of phytase was increased to $1500 \mathrm{units} / \mathrm{kg}$, improved bird performance compared with the control diets was observed.

The increased mortality of the broilers in diet 1 was due to the fact that this feed was deficient in $\mathrm{P}$, since phytic acid-P was not available to the young chicks and the requirement of $\mathrm{P}$ in young chicks is much higher than the amount offered.

\section{Pig experiment}

The results in Table 7 show that the addition of 1000 units microbial phytase $/ \mathrm{kg}$ feed has a significantly favourable effect on the apparent digestibility of P. Based on the phytic acid$\mathrm{P}$ content in the feed and the assumption that $80 \%$ of the non-phytic acid-P is digestible, it can be calculated that the digestibility of the phytic acid-P in the feeds improves, on average from -12 to $30 \%$. However, when these calculations are based on the sum of $\mathrm{IP}_{6}$, $\mathrm{IP}_{5}$ and $\mathrm{IP}_{4}$, those values oscillated from 9 to $42 \%$ respectively. The latter values should be regarded as more accurate. This implies that about $50 \%$ of the $\mathrm{P}$ from phytate-bound $\mathrm{P}$ is absorbed.

In earlier experiments by Jongbloed (1987) it was calculated that in maize-soya-bean meal diets no P from phytic acid was absorbed. This is confirmed in the present experiment.

This work was supported by the Manure Fund administered by the Ministry of Agriculture and Fisheries in The Netherlands. The authors express sincere thanks to all the co-workers in the several research centres and the Phosphorus Digestibility Working Group from the Commodity Board For Feedingstuffs for their excellent advice. 


\section{REFERENCES}

Cawley, R. W. \& Mitchell, T. A. (1968). Inhibition of wheat a-amylase by bran phytic acid. Journal of the Science of Food and Agriculture 19, 106-108.

Chappie, R. P., Yen, J. T. \& Veum, T. L. (1979). Effect of phosphorus levels and live yeast culture on phosphorus utilization in heavy finishing pigs. Journal of Animal Science 49, Suppl. 1, 99-100 Abstr.

Cromwell, G. L. \& Stahly, T. S. (1978). Study finds live yeast ineffective for swine use. Feedstuff's 50, 14

Jongbloed, A. W. (1987). Phosphorus in the feeding of pigs. Effect of diet on the absorption of phosphorus by growing pigs. PhD Thesis, IVVO Lelystad.

Knuckles, B. E. \& Betschart, A. A. (1987). Effect of phytate and other myo-inositol phosphate esters on a-amylase digestion of starch. Journal of Food Science 52, $719-721$

Nelson, T. S., Shieh, T. R., Wodzinski, R. J. \& Ware, J. H. (1968). The availability of phytate phosphorus in soya bean meal before and after treatment with a mold phytase. Poultry Science 47, 1842-1848.

Nelson, T. S., Shieh, T. R., Wodzinski, R. J. \& Ware, J. H. (1971). Effect of supplemental phylase on the utilization of phytate phosphorus by chicks. Journal of Nutrition 101, 1289-1293.

Olsen, S. R. \& Sommers, L. E. (1982). Phosphorus. In Methods of Soil Analysis, Part 2, Chemical and Microbiological Properties, pp. 403^30 [A. L. Page, R. H. Miller and D. R. Keeney, editors]. Madison, Wisconsin.

Oshima, M., Taylor, T. G. \& Williams, A. (1964). Variations in the concentration of phytic acid in the blood of the domestic fowl. Biochemical Journal 92, 42-46.

Phillippy, B. Q. \& Johnston, M. R. (1985). Determination of phytic acid in foods by ion chromatography with post-column derivatization. Journal of Food Science 50, 541-542.

Shurson, G. C, Ku, P. K. \& Miller, E. R. (1984). Evaluation of a yeast phytase product for improving phytate phosphorus bioavailability in swine diets. Journal of Animal Science 59, Suppl. 1, 106 Abstr.

Wise, A. (1983). Dietary factors determining the biological activities of phytase. Nutrition Abstracts and Reviews $53,791-806$ 